\title{
RECENZJA KSIĄŻKI: GARGILIUSZ, LEKARSTWAZ OWOCÓW I WARZYW, PRZEŁOŻYŁA TATIANA KRYNICKA, ISKŚIO UWR, WROCŁAW 2016 (SERIA BIBLIOTEKA ANTYCZNA), SS. 172
}

\author{
BOOK REVIEW: GARGILIUSZ, LEKARSTWA Z OWOCÓW I WARZYW, \\ PRZEŁ. TATIANA KRYNICKA, ISKŚSiO UWr, WROCŁAW 2016 \\ (SERIES BIBLIOTEKA ANTYCZNA), PP. 172
}

\begin{abstract}
The first Polish translation of Gargilius Martialis' treatise Medicinae de holeribus et pomis (Medicines from Fruits and Vegetables) was published in 2016 by Tatiana Krynicka. The translation is accompanied by a valuable commentary which provides the reader with rich information on botanical, medical and dietetic issues, and shows how the $3^{\text {rd }}$-century Roman author drawn on his literary sources and how he was referred to by late antique writers.
\end{abstract}

Keywords: Gargilius, medical treatise, plants, fruits

Traktat Gargiliusza Marcjalisa (ok. 200 - ok. 260 r. n.e.) Medicinae ex holeribus et pomis należy do nurtu literatury naukowej i fachowej, reprezentowanej w twórczości starożytnych Greków i Rzymian głównie przez pisma o tematyce rolniczej, medycznej i dietetycznej. W odróżnieniu jednak od uczonych autorów, Gargiliusz przekazuje łatwą do zastosowania przez wywodzącego się z jego otoczenia czytelnika - amatora, praktyczną wiedzę na temat leczniczych właściwości roślin uprawnych, którą, podobnie jak Katon Starszy czy Kolumella, zyskał na podstawie własnych doświadczeń gospodarskich, wzbogaconych o lekturę specjalistycznych pism zarówno greckich jak i rzymskich znawców przedmiotu. Wśród twórców dzieł, do których sięgał, znajdują się takie autorytety jak Pliniusz Starszy, Dioskorides, Galen oraz wspomniany już Kolumella. 
Pismo Medicinae ex holeribus et pomis, pod względem układu materiału wzorowane na Historii naturalnej Pliniusza Starszego, stanowi kompilację, opartą w znacznej mierze na wybranych passusach z Pliniuszowej encyklopedii, uzupełnionych fragmentami traktatu Dioskoridesa De materia medica oraz informacjami zaczerpniętymi z pism Galena (zwłaszcza De simplicium medicamentorum temperamentis ac facultatibus). Gargiliusz powołuje się ponadto na dzieła blisko dwudziestu autorów, o których wiedzę czerpie prawdopodobnie wyłącznie za pośrednictwem encyklopedii Pliniusza.

Przekład Tatiany Krynickiej stanowi pierwszą, a zarazem udaną próbę przybliżenia Gargiliuszowego traktatu polskiemu Czytelnikowi. Wypada dodać, iż recenzowana książka powstała jako owoc fascynacji naukowych Autorki starożytną botaniką, dietetyką i zielarstwem, które dotychczas znalazły odzwierciedlenie w monografii Świat roślin w XVII księdze ,Etymologii” Izydora z Sewilli (Krynicka 2007) oraz artykułach naukowych. Jako podstawę thumaczenia przyjęto sporządzoną przez Brigitte Maire krytyczną edycję tekstu pisma (Maire 2002), która jest opublikowaną wersją jej rozprawy doktorskiej z 2001 roku. Nota bene wydaniu temu towarzyszy pierwszy opublikowany przekład dziełka Gargiliusza na język nowożytny (francuski), który konsultowała Krynicka przygotowując własne tłumaczenie. Angielskie thumaczenie utworu przedstawiła w swojej rozprawie doktorskiej Ruth M. Taper (Taper 1980), z kolei fragmenty traktatu przełożył na język angielski John M. Riddle (Ridle 1984), który w swoim artykule „odkrył” niezauważane zarówno przez nowożytnych badaczy, jak i przez starożytnych historyków medycyny (choć cenione przez uczonych w późnym antyku i wczesnym średniowieczu) pismo Gargiliusza jako ważne źródło wiedzy z zakresu farmakologii i dietetyki. Wybrane rozdziały we własnym tłumaczeniu zamieściła Faith Wallis w opracowanym przez siebie wyborze tekstów z zakresu medycyny średniowiecznej (Wallis 2010: 34-37).

Polskie thumaczenie zostało poprzedzone wykazem stosowanych w książce skrótów (s. 5-10) oraz wstępem zatytułowanym „Kwintus Gargiliusz Marcjalis - żołnierz, pisarz i ogrodnik" (s. 11-27), który stanowi przydatne wprowadzenie do lektury. We wstępie Tatiana Krynicka przedstawia Gargiliusza Marcjalisa nie tylko jako autora traktatów o tematyce agronomicznej i medyczno-dietetycznej, ale również jako oddanego sprawom ojczyzny żołnierza i właściciela posiadłości ziemskiej w ojczystej Auzji, kolonii rzymskiej w północnej Afryce, który chętnie dzielił się swoją wiedzą i doświadczeniem w ogrodnictwie i medycynie domowej. Sporo uwagi poświęca Autorka przybliżeniu specyfiki pisma Medicinae ex holeribus et pomis, skupiając się na omawianych w nim zagadnieniach i sposobie ich przedstawienia, strukturze utworu oraz walorach języka i stylu, na którego ukształtowanie poza wysoką kulturą literacką pisarza wpłynęły również prowadzone przez niego obserwacje świata przyrody oraz doświadczenia życia żołnierskiego. W końcowej części wstępu (Od tlumaczki, s. 26-27) zamieszczono informacje dotyczące głównych założeń przekładu oraz przyjętej przez Tłumacz- 
kę metody pracy. Niezwykle ważny dla właściwego odczytania Gargiliuszowego pisemka jest rozdział poświęcony wzorcom i źródłom literackim (s. 19-22), z których autor czerpie wiedzę o leczniczych właściwościach roślin i na których opiera własną relację. Pragnąc odsłonić przed Czytelnikiem tajniki metody, jaką posłużył się pisarz, Badaczka stawia wiele pytań dotyczących pochodzenia przekazanych przez niego zaleceń i przepisów. Większość z nich pozostaje jednak bez odpowiedzi ze względu na brak dostatecznych informacji o źródłach, z których korzystał komponując, a raczej kompilując swoje dziełko. Tym niemniej uważna lektura Lekarstw pozwala Krynickiej stwierdzić, iż autora cechuje krytyczny i polemiczny stosunek do tekstów źródłowych oraz zaufanie do własnego doświadczenia (s. 20-21).

Polski tekst Lekarstw poprzedza bogata Bibliografia, podzielona na Wydania oraz Opracowania, encyklopedie i thumaczenia. Dla wygody Czytelnika proponowałabym wyodrębnić tłumaczenia jako oddzielną kategorię.

Książeczka została zaopatrzona w Wykaz miar (s. 129), który pozwala uczynić instrukcje przekazane przez Gargiliusza bardziej zrozumiałymi dla współczesnego Czytelnika, oraz starannie opracowane, szczegółowe indeksy (s. 131-166). Uwzględniono w nich rośliny i produkty pochodzenia roślinnego, nazwy własne, stosowane przez Gargiliusza łacińskie terminy odnoszące się do roślin, a także współczesne terminy botaniczne. Najobszerniejszy z indeksów, rzeczowy (s. 146-166), został uporządkowany według zagadnień, którym podporządkowane zostały poszczególne pojęcia i nazwy. Spis treści poprzedzają mapy przedstawiające północną Afrykę w czasach Gargiliusza.

Zaprezentowany w tomie przekład liczy 93 strony (s. 35-128). Rozpoznanie wymienionych w tekście warzyw, owoców i ziół ułatwiają ilustracje sporządzone przez Joannę Pieczonkę. Ze względu na konieczność identyfikacji roślin wymienionych przez Gargiliusza oraz innych przywołanych przez Krynicką autorów, a także z powodu specyfiki warstwy stylistyczno-językowej tekst Lekarstw pozostaje nie lada wyzwaniem dla tłumacza. Gargiliusz bowiem - jak zauważa Autorka - zapewne w celu przybliżenia przeciętnemu odbiorcy wiedzy przekazanej w erudycyjnych traktatach uczonych autorów, chętnie posługuje się wyrazami i zwrotami właściwymi dla języka codziennego czy wręcz potocznego (sermo vulgaris) (Krynicka 2016: 22-23). Stąd tak częste użycie w utworze czasowników złożonych i zdrobnień czy też odejście od reguł klasycznej łaciny. $Z$ drugiej strony, zastosowanie licznych figur i tropów, wprowadzenie czasowników złożonych wywodzących się ze wspólnego rdzenia, tworzenie neologizmów, także w oparciu o słowa greckie, gromadzenie wyrazów i konstrukcji synonimicznych oraz użycie greckich określeń technicznych równolegle z ich łacińskimi odpowiednikami, dowodzą szczególnej dbałości autora pisma o kunszt językowy. Zmierzenie się z tekstem traktatu Gargiliusza okazuje się zatem zadaniem niełatwym, z którego Tatiana Krynicka wywiązuje się znakomicie. Tekst, który trafia do rąk polskiego Czytelnika, jest przystępny i zrozumiały dla współczesnego odbiorcy, a jednocze- 
śnie dość wiernie naśladuje styl oryginału, Autorce bowiem udało się zachować obecne w tekście łacińskim złożenia i zdrobnienia (np. auriculum tłumaczone jako „uszko”, Med. 6, 6; 3, 14 czy cauliculum wyrażone jako „kapustka” w tytule rozdziału, Med. 30), a także oddać w języku polskim niektóre spośród tropów i figur lub przynajmniej odnotować ich użycie i objaśnić je w przypisach. I tak na przykład w przyp. 5 na s. 38 i przyp. 7 na s. 39 Badaczka przytacza fragmenty oryginalnego tekstu, aby zinterpretować zastosowane przez Gargiliusza aliteracje, chiazm oraz peryfrazę. Niektóre wyrazy zostały dodane w thumaczeniu, by nadać tekstowi spójność i płynność, co każdorazowo zaznaczone jest poprzez umieszczenie ich w nawiasach kwadratowych.

Niezwykle pomocny podczas lektury przekładu Lekarstw jest rzetelny i wieloaspektowy komentarz w formie przypisów, który sytuuje traktat Gargiliusza na szerokim tle antycznej literatury naukowo-fachowej. Zawarto w nim wiele cennych uwag i objaśnień dotyczących zagadnień medycznych, działalności wzmiankowanych przez Gargiliusza starożytnych lekarzy, identyfikacji opisywanych roślin i wykorzystania ich walorów dietetycznych, pojęć i nazw łacińskich, w tym także greckiej etymologii nazewnictwa łacińskiego (np. opium w przyp. 99, s. 68 i diacodion w przyp. 102, s. 69), oraz cech stylu i języka utworu. Liczne są również odwołania do traktatów medycznych (De materia medica Dioskoridesa, De medicina Celsusa, De alimentorum facultatibus Galena), agronomicznych (De agri cultura Katona, De re rustica Kolumelli), z których pisarz mógł czerpać swoją wiedzę, oraz wskazania na zapożyczenia z utworów o podobnej tematyce, zwłaszcza Historii naturalnej Pliniusza Starszego. Zalecenia przekazane przez Gargiliusza często są zestawione z informacjami pochodzącymi ze źródeł, z których korzystał. Dodatkowo Autorka przywołuje przykłady późniejszych nawiązań do traktatu Gargiliusza, ze szczególnym uwzględnieniem jego recepcji w encyklopedycznym kompendium Izydora z Sewilli, wiernego czytelnika i kompilatora Lekarstw. Tak skonstruowany komentarz świadczy o tym, iż Badaczka doskonale orientuje się w omawianych zagadnieniach. Jak informuje Krynicka we wstępie, komentarz został sporządzony na podstawie przypisów opracowanych przez Brigitte Maire do edycji, na której opiera się polskie tłumaczenie (Krynicka 2016: 26). Widać jednak, że pierwotna wersja komentarza została rozszerzona przez Autorkę, o czym świadczą uwagi o charakterze polemicznym oraz odwołania do najnowszej literatury przedmiotu. Na przykład w przyp. 246 na s. 110 Krynicka proponuje odmienną niż Maire interpretację wyrażenia mollique igniculo argumentując, iż gęstość opisywanego przez Gargiliusza leku wskazuje na użycie deminutivum igniculum we właściwym znaczeniu, na określenie bardzo wolnego ognia. $Z$ kolei sprostowania wymaga komentarz na temat znaczenia nazwy cucurbita, która w tekście została poprawnie przetłumaczona jako „tykwa" (Med. 6, 1), w przypisie jednak (przyp. 38, s. 51) Autorka informuje, że Gargiliusz mógł opisywać w tym miejscu dynię, określaną w języku łacińskim w taki sam sposób. Tymczasem dynia nie mogła być znana Gargiliuszowi, jak również innym 
autorom starożytnym, ponieważ trafiła do Europy z Ameryki Południowej dopiero w XV wieku za sprawą Krzysztofa Kolumba.

Tekst został starannie przygotowany pod względem redakcyjnym. W Bibliografii nie uwzględniono poprzedzonego obszernym Wstępem najnowszego francuskiego tłumaczenia traktatu Gargiliusza autorstwa Brigitte Maire (Maire 2007). Jak zaznacza jego autorka, nowy przekład (w odróżnieniu od poprzedniego, który towarzyszył krytycznemu wydaniu tekstu Lekarstw) jest przeznaczony dla szerszego grona odbiorców, zainteresowanych zagadnieniami z dziedziny botaniki, a zwłaszcza historią roślin i ich zastosowaniem w starożytności (Maire 2007: xxxiii). Krynickiej nie udało się także sięgnąć do artykułu tej samej autorki poświęconego - podobnie jak dwa jej wcześniejsze teksty - warstwie językowej Lekarstw (Maire 2003: 147-160). W Bibliografii zabrakło również przywołanej już wyżej edycji poświęconej średniowiecznym tekstom medycznym opracowanej przez F. Wallis, w której zamieszczono przekłady wybranych rozdziałów pisma Gargiliusza (Wallis 2010). Sugerowałabym także wykorzystanie encyklopedycznego opracowania Andrew Dalby'ego Food in the Ancient World from A to $Z$ (Dalby 2003), które mogłoby dostarczyć informacji przydatnych przy identyfikowaniu i opisywaniu roślin (choćby w kwestii właściwego rozumienia nazwy cucurbita, Med. 6, 1) oraz ich właściwości.

Prezentowany przekład może zainteresować zarówno badaczy rzymskiej literatury okresu późnego Cesarstwa, jak i historyków medycyny, dla których traktat Gargiliusza pozostaje jedynym zachowanym w całości lub prawie w całości ${ }^{1}$ świadectwem dokumentującym istnienie piśmiennictwa medycznego w Cesarstwie Rzymskim w III w. n.e. Publikacja Tatiany Krynickiej nie powinna pozostać niezauważona, gdyż pozwala ona $\mathrm{w}$ istotny sposób uzupełnić wiedzę polskiego Czytelnika na temat tradycji literatury specjalistycznej o charakterze użytkowym w świecie antycznym, w naturalny sposób nawiązując do prowadzonych dotychczas badań w tej dziedzinie ${ }^{2}$.

\section{Bibliografia}

Dalby, A., (2003). Food in the Ancient World from A to Z. London-New York: Routledge.

Krynicka, T., (2007). Świat roślin w XVII księdze „Etymologii” Izydora z Sewilli. Lublin: Towarzystwo Naukowe KUL.

Krynicka, T. (przekł.), (2016). Gargiliusz. Lekarstwa z owoców i warzyw. Wrocław: ISKŚiO UWr. Maire, B. (red.) (2002). Quintus Gargilius Martialis. Medicinae ex holeribus et pomis. Texte, traduction et commentaire. Paris: Les Belles Lettres.

${ }^{1}$ Nie wiadomo, czy traktat posiadał wstęp i zakończenie.

${ }^{2}$ Mam tu na myśli przede wszystkim wieloletnie studia nad rzymską literaturą rolniczą prowadzone przez Ireneusza Mikołajczyka, których efektem jest poświęcone jej monograficzne opracowanie (Mikołajczyk 2004) oraz przekłady traktatów agronomicznych Warrona, Kolumelli, Palladiusza i Katona. 
Maire, B., (2003). Actions thérapeutiques ou gestes littéraires: le lexique des Medicinae de Gargilius Martialis, [w:] F. Gaide, F. Biville, (éd.). Manus medica. Actions et gestes de l'officiant dans les textes médicaux latins. Questions de thérapeutique et de lexique. Actes du Colloque tenu à l'Université Lumière-Lyon II, les 18 et 19 septembre 2001. Aix-en-Provence: Publications de l'Université de Provence, 147-160.

Maire, B., (2007). Se soigner par les plantes. Les Remèdes de Gargile Martial. Lausanne: Éditions BHMS.

Mikołajczyk, I., (2004). Rzymska literatura agronomiczna. Toruń: Wydawnictwo Naukowe UMK.

Riddle, J.M., (1984). "Gargilius Martialis as a Medical Writer". Journal of the History of Medicine and Allied Sciences, 39 (4), 408-429.

Tapper, R.M., (1980). The Materia Medica of Gargilius Martialis. Ph.D. Dissertation. University of Wisconsin.

Wallis, F., (red.) (2010). Medieval Medicine: A Reader. Toronto: University of Toronto Press. 